\title{
Pengaruh Kompensasi, Beban Kerja dan Motivasi Kerja Terhadap Kepuasan Kerja Pegawai di Sub Bagian Kepegawaian dan Keuangan Dinas Pertanian Provinsi Daerah Istimewa Yogyakarta
}

\author{
Indah Fajar Yuliani ${ }^{1}$, Nany Noor Kurniyati ${ }^{2}$ \\ Universitas Widya Mataram \\ Email1) Indahfajar884@gmail.com \\ Universitas Widya Mataram \\ Email' ${ }^{2)}$ anykurniyati@gmail.com
}

\begin{abstract}
In this study, the population was an employee in the Personnel and Finance Sub-Department of the Yogyakarta Provincial Agriculture Office of 30 people. The entire population is also sampled. The data retrieval method uses questionnaires and questionnaire assessments using the Likert scale. The analysis was carried out using multiple regression analysis and hypothesis testing. Multiple regression analysis in this study was $Y=1,284+0.714 \times 1+$ $0.241 \times 2+0.269 \times 3$. Based on the Ttest calculation is as follows: The influence of compensation shows a number of 2.149 and the significance level of 0.037, which means compensation significantly influences employee job satisfaction. The effect of workload shows t count of 0.870 and the significance level of 0.392, which means the workload has no effect on employee job satisfaction. The effect of work motivation shows $t$ count of 2.149 and significance of 0.041, which means work motivation significantly influences employee satisfaction. Based on the F test calculation is as follows: the effect of compensation, workload and work motivation on employee job satisfaction shows f count of 4.545 and the significance level of 0.011, which means that compensation, workload and work motivation together have an effect on employee job satisfaction In the Personnel and Finance Sub-Department of the Provincial Agriculture Service of the Special Region of Yogyakarta.
\end{abstract}

Keywords: Compensation, Workload, Work Motivation, Employee Job Satisfaction

\section{A. PENDAHULUAN}

Dalam era globalisasi seperti saat ini, potensi sumber daya manusia harus dimanfaatkan sebaik-baiknya, sehingga dapat memberikan suatu pencapaian atau target yang optimal terhadap instansi atau perusahaan. Oleh karena itu, instansi atau perusahaan harus memikirkan cara yang tepat untuk mengelola sumber daya manusianya dengan baik. Pengelolaan sumber daya manusia tidak hanya dalam lingkup rekruitmen atau 
mendapatkan sumber daya manusia yang berkualitas, tetapi yang tidak kalah penting adalah menjaga keberadaan sumber daya manusia agar kinerja pegawai meningkat. Faktor penentu meningkatnya kinerja karyawan salah satunya adalah kepuasan kerja. Sinambela mengemukakan (2016:486) salah satu aspek yang dapat meningkatkan kinerja pegawai adalah adanya kepuasan kerja dari pegawai. Suatu perusahaan atau instansi harus memerhatikan tingkat kepuasan kerja pegawainya, apabila kepuasan kerja pegawai rendah maka kinerja pegawai menurun. Pendapat tersebut sejalan dengan hasil penelitian Damayanti dkk (2018:84), bahwa ada pengaruh yang kuat antara kepuasan kerja terhadap kinerja karyawan.

Kepuasan kerja adalah salah satu aspek bagi pegawai dalam menjalankan pekerjaannya. Pegawai yang memiliki rasa puas pada pekerjaannya akan menunjukkan sikap yang lebih positif, sehingga dapat bekerja dengan baik. Menurut Sinambela (2016:303) kepuasan kerja adalah perasaan sesorang terhadap pekerjaannya yang dihasilkan oleh usahanya sendiri (internal) dan didukung oleh hal-hal yang dari luar dirinya (eksternal), atas keadaan kerja, hasil kerja, dan kerja itu sendiri. Dalam penelitian ini beberapa faktor yang dapat memengaruhi kepuasan kerja pegawai antara lain kompensasi, beban kerja, dan motivasi kerja pegawai.

Faktor pertama adalah kompensasi, tentunya kerja keras seorang pegawai harus diberi imbalan yang layak, dan sesuai dengan tenaga serta pemikiran yang telah mereka kerahkan untuk perusahaan. Pontoh (2014:111) menyatakan bahwa adanya pengaruh langsung positif dan signifikan dari kompensasi terhadap kepuasan kerja serta pengaruh langsung positif dan signifikan kompensasi terhadap kinerja karyawan. Kompensasi menjadi komponen yang berpengaruh bagi karyawan, jika pemberian kompensasi sudah sesuai dengan standar dan layak maka kepuasan kerja pegawai dapat meningkat. Pemberian kompensasi juga harus memerhatikan seberapa besar beban kerja pegawai, jika pemberian kompensasi sesuai dengan beban kerja yang diterima pegawai, maka pegawai akan merasa puas. Dengan seimbangnya beban kerja dan kemampuan pegawai dapat meningkatkan kualitas kerja pada pegawai, sehingga pegawai akan puas terhadap pekerjaannya. Beban kerja merupakan faktor yang penting bagi pegawai, beban kerja sebagai acuan kepuasan kerja pegawai. Berat atau ringannya suatu beban kerja juga dipengaruhi oleh motivasi kerja dari pegawai.

Menurut Sedarmayanti (2017:154) motivasi adalah kekuatan yang mendorong seseorang untuk melakukan suatu tindakan atau tidak pada hakikatnya ada secara internal dan eksternal positif ataupun negatif untuk mengarahkannya sangat bergantung pada ketanggguhan pimpinan. Sinambela (2016:317) mengemukakan bahwa peningkatan motivasi memiliki potensi dalam peningkatan kepuasan kerja, dalam hal ini terdapat hubungan yang signifikan antara motivasi kerja dengan kepuasan kerja.

Berdasarkan uraian latar belakang di atas, maka dirumuskan masalah sebagai berikut: (1)Apakah kompensasi berpengaruh secara parsial terhadap kepuasan kerja pegawai di Sub Bagian Kepegawaian dan Keuangan Dinas Pertanian Provinsi Daerah Istimewa Yogyakarta?; (2) Apakah beban kerja berpengaruh secara parsial terhadap 
kepuasan kerja pegawai di Sub Bagian Kepegawaian dan Keuangan Dinas Pertanian Provinsi Daerah Istimewa Yogyakarta?; (3) Apakah motivasi kerja berpengaruh secara parsial terhadap kepuasan kerja pegawai di Sub Bagian Kepegawaian dan Keuangan Dinas Pertanian Provinsi Daerah Istimewa Yogyakarta?; (4) Apakah kompensasi, beban kerja dan motivasi kerja secara bersama-sama berpengaruh terhadap pegawai di Sub Bagian Kepegawaian dan Keuangan Dinas Pertanian Provinsi Daerah Istimewa Yogyakarta?.

\section{B. KAJIAN LITERATUR DAN TEORI}

\section{Kompensasi}

Kompensasi merupakan faktor yang penting dalam menentukan kepuasan kerja pegawai. Sinambela (2016:220) mendefinisikan bahwa kompensasi adalah total dari semua penghargaan yang diberikan kepada para pegawai sebagai imbalan atas jasa mereka berikan kepada organisasi. Menurut Sedarmayanti (2017:173) kompensasi adalah segala sesuatu yang diterima oleh pegawai sebagai balas jasa atas kontribusinya kepada perusahaan/organisasi. Sedangkan menurut Hasibuan (2014:118) kompensasi adalah semua pendapatan yang berbentuk uang, barang langsung atau tidak langsung yang diterima pegawai sebagai imbalan atas jasa yang telah diberikan kepada perusahaaan. Kompensasi merupakan segala sesuatu yang diterima para pegawai sebagai balas jasa untuk kerja mereka( Handoko, 2012:155). Dari pengertian kompensasi menurut para ahli di atas dapat disimpulkan bahwa kompensasi merupakan balas jasa yang diberikan secara periodik oleh orgnisasi kepada pegawainya dengan berpedoman atas perjanjian yang disepakati bersama.

Indikator yang digunakan pada penelitian ini mengacu dari definisi jenis-jenis kompensasi menurut Hasibuan (2014:118). Indikator kompensasi antara lain; 1) Balas jasa yang dibayarkan secara periodik kepada pegawai tetap, 2) Mempunyi jaminan yang pasti, 3) Berpedoman atas perjanjian yang disepakati bersama, 4) Mempunyai prinsip adil, 5) Sebagai sarana untuk meningkatkan kesejahteraaan pegawai.

\section{Beban Kerja}

Beban kerja adalah pekerjaan yang diberikan kepada pegawai untuk diselesaikan dalam kurun waktu tertentu (Koesmowidjojo, 21:2017). Sedangkan dalam Permendagri No.12/2008 beban kerja adalah besaran pekerjan yang harus dipikul oleh suatu jabatan atau unit organisasi dan merupakan hasil kali antara volume kerja dan normal waktu. Selanjutnya Paramitadewi (2017) menyatakan bahwa beban kerja merupakan sejauh mana kapasitas individu pekerja dibutuhkan dalam menyelesaikan tugas-tugas yang diberikan kepadanya, yang dapat diindikasikan dari jumlah pekerjan yang harus dilakukan oleh pegawai, dan waktu/batasan yang dimiliki oleh pekerja dalam menyelesaikan tugasnya, serta pandangan subjektif individu tersebut sendiri mengenai pekerjaan yang diberikan kepadanya. 
Dari pengertian di atas dapat disimpulkan bahwa beban kerja adalah jumlah atau besaran suatu pekerjaan untuk diselesikan oleh seseorang dengan periode waktu yang telah ditentukan. Indikator-indikator yang dapat digunakan untuk mengukur beban kerja menurut Koesmowidjojo (2017:33) yaitu :

1) Kondisi Pekerjaan

2) Penggunaan Waktu Kerja

3) Target yang harus dicapai

\section{Motivasi Kerja}

Motivasi adalah kekuatan yang mendorong seseorang untuk melakukan suatu tindakan atau tidak yang pada hakikatnya ada secara internal dan eksternal positif ataupun negatif untuk mengarahkannya sangat bergantung pada ketangguhan pimpinan. Motivasi kerja adalah sesuatu yang menimbulkan dorongan, semangat kerja atau pendorong semangat kerja. Motif adalah daya pendorong yang mendorong manusia bertindak atau suatu tenaga dalam diri manusia yang menyebabkan manusia bertindak (Sedarmayanti, 2017:154). Seperti yang dikemukakan oleh Hasibuan ( 2014:141) bahwa motivasi adalah hal yang menyebabkan, menyalurkan, dan mendukung perilaku manusia, supaya mau bekerja giat dan antusias mencapai hasil yang optimal. Sedangkan menurut Sulistiani Rosidah ( 2018:279) motivasi merupakan hasrat untuk berkembang yang bersumber dari kekuatan internal seseorang.

Dari teori hierarki kebutuhan yang dikemukakan oleh Abraham Maslow dalam Hasibuan (2014:154), dapat disimpulkan indikator motivasi kerja antara lain: 1) Kebutuhan untuk mempertahankan hidup, 2) Setiap pegawai membutuhan keamanan, 3) Keinginan setiap pegawai agar diterima dalam pergaulan kelompok pekerja dan masyarakat lingkungannya, 5) Setiap pegawai ingin berbeda dari pegawai lainnya.

\section{Kepuasan Kerja}

Menurut Sinambela (2016:303) kepuasan kerja adalah perasaan puas seseorang terhadap pekerjaannya yang dihasilkan oleh usahanya sendiri (internal) dan yang didukung oleh hal-hal yang dari luar. Kepuasan kerja adalah sikap emosional yang menyenangkan dan mencintai pekerjannya (Hasibuan, 2014:2202). Sikap ini dicerminkan oleh moral kerja, kedisplinan, pegawai meningkat. Selanjutnya Handoko (2012:193) mendefinisikan kepuasan kerja (job satisfaction) adalah emosional yang menyenangkan atau tidak menyenangkan dengan mana para pegawai memandang pekerjaan mereka. Kepuasan kerja mencerminkan perasaan seseorang terhadap pekerjaan. Ini nampak dalam sikap positif pegawai terhadap pekerjaan dan segala sesuatu yang dihadapi di lingkungan kerjanya. Dari pengertian kepuasan kerja di atas dapat disimpulkan bahwa, kepuasan kerja adalah perasaan emosional seorang pegawai yang senang dan puas terhadap pekerjaannnya.

Hasibuan (2014:202) mengemukakan bahwa tolak ukur tingkat kepuasan yang mutlak tidak ada karena setiap individu pegawai berbeda standar kepuasannya. Indikator 
kepuasan kerja dapat diukur dengan tiga indikator antara lain :

1) Kedisplinan

Kedisplinan adalah kesadaran dan kesediaan seseorang menaati semua peraturan perusahaan dan norma-norma sosial yang berlaku.

2) Moral Kerja

Ini merupakan kesepakatan batiniah yang muncul dari dalam diri seseorang atau organisasi untuk mencapai tujuan tertentu sesuai dengan mutu yang ditetapkan.

3) Turnover pegawai

Keinginan pegawai untuk mengundukan diri secara sukarela dari organisasi atau perusahaan.

Penelitian tentang kepuasan kerja sudah banyak dilakukan oleh para peneliti sebelumnya. Seperti hasil penelitian yang dilakukan oleh Zaki dan Marzolina (2018), bahwa kompensasi berpengaruh positif dan signifikan terhadap kepuasan kerja karyawan yang bersangkutan. Beban kerja berpengaruh negatif dan signifikan terhadap kepuasan kerja, setiap peningkatan beban kerja yang dirasakan karyawan berpotensi menurunkan tingkat kepuasan kerja karyawan yang bersangkutan. Kepuasan kerja berpengaruh negatif dan signifikan terhadap turnover intention. Kepuasan kerja karyawan yang rendah akan berpotensi meningkatnya turnover intention pada karyawan. Sebaliknya, jika kepuasan kerja karyawan meningkat maka turnover intention pada karyawan menurun.

\section{METODE PENELITIAN}

Penelitian ini dilakukan di Dinas Pertanian Provinsi Daerah Istimewa Yogyakarta yang beralamat di Jl.Gondosuli No,6, Semaki, Umbulharjo, Kota Yogyakarta, Daerah Istimewa Yogyakarta yaitu pada Sub Bagian Kepegawaian dan Keuangan. Dalam penelitian ini variabel terdiri dari variabel bebas (independen) dan variabel terikat (dependent). Variabel bebas (independent) atau variabel penjelas adalah variabel yang memengaruhi atau yang menjadi sebab berubahnya variabel terpengaruh (Supriyanto dan Maharani, 2013:30). Variabel bebas (independent) meliputi kompensasi, beban kerja dan motivasi kerja sedangkan. Variabel terikat (dependent) adalah variabel yang tercakup di dalam hipotesis penelitian, yang keragamannya (variabelitasnya) ditentukan atau tergantung atau dipengaruhi variabel lainnya (Supriyanto dan Maharani, 2013:30). Variabel terikat (dependent) meliputi kepuasan kerja.

Terkait dengan penjelasan mengenai variabel dalam penelitian ini, peneliti memberikan definisi operasional variabel untuk memudahkan pemberian definisi dalam suatu variabel serta indikator sebagai tolak ukur dalam setiap variabel. 
Tabel 1.Definisi Operasional Variabel

\begin{tabular}{|c|c|c|}
\hline Variabel & Definisi Operasional & Indikator \\
\hline $\begin{array}{l}\text { Kompensasi } \\
\text { (X1) }\end{array}$ & $\begin{array}{l}\text { Kompensasi } \\
\text { merupakan balas } \\
\text { jasa yang diberikan } \\
\text { secara periodik oleh } \\
\text { organisasi kepada } \\
\text { pegawainya dengan } \\
\text { berpedoman atas } \\
\text { perjanjian yang } \\
\text { disepakati bersama. }\end{array}$ & $\begin{array}{l}\text { Balas jasa yang dibayarkan secara } \\
\text { periodik kepada pegawai tetap. } \\
\text { - } \text { Mempunyai jaminan yang pasti. } \\
\text { - Berpedoman atas perjanjian yang } \\
\text { disepakati bersama. } \\
\text { - Mempunyai prinsip adil } \\
\text { - Sebagai sarana untuk meningkatkan } \\
\text { kesejahteraan pegawai }\end{array}$ \\
\hline $\begin{array}{l}\text { Beban Kerja } \\
\text { (X2) }\end{array}$ & $\begin{array}{l}\text { Beban kerja adalah } \\
\text { pekerjaan yang } \\
\text { diberikan kepada } \\
\text { pegawai untuk } \\
\text { diselesaikan dalam } \\
\text { kurun waktu tertentu }\end{array}$ & $\begin{array}{l}\text { - Kondisi Pekerjaan. } \\
\text { - Penggunaan Waktu Kerja. } \\
\text { - Target yang harus dicapai. }\end{array}$ \\
\hline $\begin{array}{c}\text { Motivasi } \\
\text { Kerja (X3) }\end{array}$ & $\begin{array}{l}\text { Motivasi adalah hal } \\
\text { yang menyebabkan, } \\
\text { menyalurkan, dan } \\
\text { mendukung perilaku } \\
\text { manusia, supaya } \\
\text { mau bekerja giat dan } \\
\text { antusias mencapai } \\
\text { hasil yang optimal. }\end{array}$ & $\begin{array}{l}\text { - Kebutuhan untuk mempertahankan } \\
\text { hidup. } \\
\text { - Setiap pegawai membutuhkan } \\
\text { keamanan. } \\
\text { - Keinginan setiap pegawai agar diterima } \\
\text { dalam pergaulan kelompok pekerja dan } \\
\text { masyarakat lingkungannya } \\
\text { - Keinginan setiap pegawai agar dihargai } \\
\text { dan diperhatikan oleh pimpinan. } \\
\text { - Setiap pegawai ingin berbeda dari } \\
\text { pegawai lainnya }\end{array}$ \\
\hline $\begin{array}{l}\text { Kepuasan } \\
\text { Kerja (Y) }\end{array}$ & $\begin{array}{l}\text { Kepuasan kerja } \\
\text { adalah sikap } \\
\text { emosional yang } \\
\text { menyenangkan } \\
\text { dan mencintai } \\
\text { pekerjannya. Sikap } \\
\text { ini dicerminkan } \\
\text { oleh moral kerja, } \\
\text { kedisplinan, pegawai } \\
\text { meningkat }\end{array}$ & $\begin{array}{l}\text { - Kedisplinan } \\
\text { - Moral Kerja } \\
\text { - Turnover Pegawai }\end{array}$ \\
\hline
\end{tabular}


Metode pengambilan data dilakukan dengan kuesioner dengan skala pengukuran memakai model skala pengukuran likert. Uji instrument dalam penelitian menggunakan metode uji validitas dan uji reliabilitas. Uji validitas merupakan suatu instrumen dinyatakan sahih jika instrumen itu mengukur apa saja yang ingin diungkapkan, mampu menembak dengan jitu sasaran yang ditembak. (Supriyanto dan Maharani, 2013 : 47) Uji relibilitas dalam pandangan positivistik (kuantitatif), suatu data dinyatakan reliabel apabila dua atau lebih peneliti dalam obyek yang sama menghasilkan data yang sama, atau peneliti sama dalam waktu berbeda menghasilkan data yang sama, atau sekelompok data bila dipecah menjadi dua menunjukkan data yang berbeda (Sugiyono, 2018:268).

\section{POPULASI DAN SAMPEL}

Populasi dalam penelitian ini adalah seluruh pegawai pada sub bagian kepegawaian dan keuangan berjumlah 30 orang dengan menggunakan teknik sampling jenuh. Sugiyono (2018:85) menyatakan bahwa sampling jenuh adalah teknik penentuan sampel bila semua anggota polpulasi digunakan sebagai sampel. Pendekatan dalam penelitian ini adalah penelitian kuantitatif.

\section{HASIL DAN PEMBAHASAN}

\section{Uji Validitas}

Uji validitas merupakan suatu instrumen dinyatakan sahih jika instrumen itu mengukur apa saja yang ingin diungkapkan, mampu menembak dengan jitu sasaran yang ditembak. (Supriyanto dan Maharani, 2013 : 47) Pengambilan keputusan berdasarkan nilai value/nilai signifikansi $0,05(5 \%)$. Dengan degree of freedom $/(\mathrm{df})=(\mathrm{n}-2)$ atau 30 $2=28$ dan alpha sebesar 0,3610 . Item pernyataan dikatakan valid apabila $r_{\text {hitung }}$ positif dan $r_{\text {hitung. }}>r_{\text {tabel. }}$ Item pernyataan dikatakan tidak valid apabila $r_{\text {hitung }}$ ngatif dan $r_{\text {hitung }}$ $<\mathrm{r}_{\text {tabel }}$. Hasil perhitungan uji validitas instrumen variabel-variabel dalam penelitian ini, adalah sebagai berikut:

1) Variabel Kompensasi (X1)

Tabel 2. Hasil Uji Validitas Variabel Kompensasi

\begin{tabular}{ccccc}
\hline No & Butir & $\mathbf{r}_{\text {hitung }}$ & $\mathbf{r}_{\text {tabel }}$ & Keterangan \\
\hline 1 & X1.1 & 0,625 & 0,3610 & Valid \\
2 & X1.2 & 0,621 & 0,3610 & Valid \\
3 & X1.3 & 0,753 & 0,3610 & Valid \\
4 & X1.4 & 0,812 & 0,3610 & Valid \\
5 & X1.5 & 0,805 & 0,3610 & Valid \\
6 & X1.6 & 0,842 & 0,3610 & Valid \\
\hline
\end{tabular}

Sumber: hasil olah data primer 2021 
Berdasarkan hasil uji validitas yang tertera pada tabel 2, dapat diketahui bahwa masing-masing pernyataan dari variabel kompensasi yang terdiri dari 6 butir pernyataan, memiliki nilai korelasi yang lebih besar dari $r_{\text {tabel }}(0,3610)$, sehingga keseluruhan pernyataan pada variabel kompensasi dinyatakan valid.

2) Variabel Beban Kerja (X2)

Tabel 3. Hasil Uji Validitas Variabel Disiplin Kerja

\begin{tabular}{ccccc}
\hline No & Butir & $\mathbf{r}_{\text {hitung }}$ & $\mathbf{r}_{\text {tabel }}$ & Keterangan \\
\hline 1 & X2.1 & 0,825 & 0,3610 & Valid \\
2 & X2.2 & 0,779 & 0,3610 & Valid \\
3 & X3.3 & 0,934 & 0,3610 & Valid \\
4 & X4.4 & 0,913 & 0,3610 & Valid \\
5 & X5.5 & 0,831 & 0,3610 & Valid \\
\hline
\end{tabular}

Sumber: hasil olah data primer 2021

Berdasarkan hasil uji validitas pada tabel 3 dapat diketahui bahwa masingmasing butir pernyataan dari variabel beban kerja yang terdiri dari 5 butir pernyataan, memiliki nilai korelasi yang lebih besar dari $r_{\text {tabel }}(0,3610)$, sehingga keseluruhan butir-butir pernyataan pada variabel beban kerja dinyatakan valid.

3) Variabel Motivasi Kerja (X3)

Tabel 4. Hasil Uji Validitas Variabel Motivasi Kerja (X3)

\begin{tabular}{ccccc}
\hline No & Butir & $\mathbf{r}_{\text {hitung }}$ & $\mathbf{r}_{\text {tabel }}$ & Keterangan \\
\hline 1 & X3.1 & 0,801 & 0,3610 & Valid \\
2 & X3.2 & 0,656 & 0,3610 & Valid \\
3 & X3.3 & 0,718 & 0,3610 & Valid \\
4 & X3.4 & 0,771 & 0,3610 & Valid \\
5 & X3.5 & 0,802 & 0,3610 & Valid \\
6 & X3.6 & 0,748 & 0,3610 & Valid \\
7 & X3.7 & 0,708 & 0,3610 & Valid \\
8 & X3.8 & 0,641 & 0,3610 & Valid \\
9 & X3.9 & 0,761 & 0,3610 & Valid \\
10 & X3.10 & 0,755 & 0,3610 & Valid \\
\hline
\end{tabular}

Sumber: hasil olah data primer 2021

Berdasarkan hasil uji validitas pada tabel 4 dapat diketahui bahwa masingmasing butir pernyataan dari variabel motivasi kerja (X3) yang terdiri dari 10 butir 
pernyataan, memiliki nilai korelasi yang lebih besar dari $\mathrm{r}_{\text {tabel }}(0,3610)$, sehingga keseluruhan butir-butir pernyataan pada variabel motivasi kerja dinyatakan valid

4) Variabel Kepuasan Kerja Pegawai (Y)

Tabel 5.Hasil Uji Validitas Variabel Kepuasan Kerja Pegawai

\begin{tabular}{ccccc}
\hline No & Butir & $\mathrm{r}_{\text {hitung }}$ & $\mathrm{r}_{\text {tabel }}$ & Keterangan \\
\hline 1 & Y.1 & 0,628 & 0,3610 & Valid \\
2 & Y.2 & 0,670 & 0,3610 & Valid \\
3 & Y.3 & 0,776 & 0,3610 & Valid \\
4 & Y.4 & 0,763 & 0,3610 & Valid \\
5 & Y.5 & 0,766 & 0,3610 & Valid \\
6 & Y.6 & 0,827 & 0,3610 & Valid \\
7 & Y.7 & 9,821 & 0,3610 & Valid \\
8 & Y.8 & 0,724 & 0,3610 & Valid \\
9 & Y.9 & 0,744 & 0,3610 & Valid \\
\hline
\end{tabular}

Sumber: hasil olah data primer 2021

Berdasarkan hasil uji validitas pada tabel 5 dapat diketahui bahwa masingmasing butir pernyataan dari variabel kepuasan kerja pegawai (Y) yang terdiri dari 9 butir pernyataan, memiliki nilai korelasi yang lebih besar dari $\mathrm{r}_{\text {tabel }}(0,3610)$, sehingga keseluruhan butir-butir pernyataan pada variabel kepuasan kerja pegawai dinyatakan valid.

Dalam penelitian ini responden sebanyak 30 responden dengan menggunakan taraf pengambilan keputusan berdasarkan nilai signifikansi $5 \%$ dengan $r_{\text {tabel }}=n-2$ yaitu $30-2=28$, maka $r_{\text {tabel }}=0,3610$. Item pernyataan dikatakan valid apabila $r_{\text {hitung }}$ positif dan $r_{\text {hitung. }}>r_{\text {tabel. }}$ Item pernyataan dikatakan tidak valid apabila $r_{\text {hitung }}$ ngatif dan $r_{\text {hitung }}$ $<\mathrm{r}_{\text {tabel }}$. Dari uji validitas dalam penelitian ini dapat diketahui bahwa masing-masing variabel mempunyai butir pernyataan yang seluruhnya dinyatakan valid, karena $r_{\text {hitung }}$ lebih besar dari $\mathrm{r}_{\text {tabel }}(0,3610)$.

\section{Uji Reliabilitas}

Pengujian reliabilitas instrumen dalam penelitian ini menggunakan Cronbach's Alpha menunjukkan seberapa baik item-item yang terdapat pada model berkorelasi secara positif terhadap satu sama lain. Berdasarkan tingkat keandalan Cronbach's Alpha, penelitian ini akan menggunakan batas nilai Cronbach's Alpha $>0,6$ karena dinilai sudah termasuk andal untuk digunakan dalam analisis selanjutnya (Sekaran dan Bougie, 2010: 324-325). 
Tabel 6.Hasil Uji Reliabilitas

\begin{tabular}{|l|c|c|c|}
\hline \multicolumn{1}{|c|}{ Variabel } & Cronbach's Alpha & N of Items & Keterangan \\
\hline Kompensasi & 0,835 & 6 & Reliabel \\
\hline Beban Kerja & 0,902 & 5 & Reliabel \\
\hline Motivasi Kerja & 0,903 & 10 & Reliabel \\
\hline Kepuasan Kerja & 0,899 & 9 & Reliabel \\
\hline
\end{tabular}

Sumber: hasil olah data primer 2021

Berdasarkan pengujian reliabilitas menunjukkan bahwa semua variabel yang dijadikan sebagai instrumen adalah reliabel atau dapat dipercaya dan dapat digunakan sebagai alat pengumpul data.

\section{Analisis Regresi Linier Berganda}

Analisis regresi linier berganda digunakan untuk mengetahui pengaruh variabel kompensasi $\left(\mathrm{x}_{1}\right)$, beban kerja $\left(\mathrm{x}_{2}\right)$ dan motivasi kerja $\left(\mathrm{x}_{3}\right)$ terhadap kepuasan kerja pegawai (y) di Sub Bagian Kepegawaian dan Keuangan Dinas Pertanian Provinsi Daerah Istimewa Yogyakarta. Berdasarkan hasil pengolahan data dengan bantuan program SPSS 22, didapatkan hasil sebagai berikut:

Tabel 6.Hasil Analisis Regresi Linier Berganda

\begin{tabular}{lll}
\hline Variabel Bebas & Koefisien Regresi & Kontanta \\
\hline Kompensasi & 0,714 & \\
Beban Kerja & 0,241 & 1,284 \\
Motivasi Kerja & 0,269 & \\
\hline
\end{tabular}

Sumber: hasil olah data primer 2021

Berdasrkan tabel 5.10 di atas dapat dibuat persamaan regresi linear berganda sebagai berikut:

$\mathrm{Y}=\mathrm{a}+\mathrm{b} 1 \mathrm{X} 1+\mathrm{b} 2 \mathrm{X} 2+\mathrm{b} 3 \mathrm{X} 3$

$\mathrm{Y}=1,284+0,714 \mathrm{X} 21+0,241 \mathrm{X} 2+0,269 \mathrm{X} 3$

Keterangan:

Y: Kepuasan kerja pegawai

a: Konstanta

b1,b2,b3: koefisien regresi

$\mathrm{x}_{1}$ : Kompensasi

$\mathrm{x}_{2}$ : Beban Kerja

$\mathrm{x}_{3}$ : Motivasi Kerja 
Dari persamaan tersebut dapat diambil kesimpulan bahwa:

1) Konstanta sebesar 1,284 menyatakan bahwa jika tidak ada kompensasi $\left(\mathrm{x}_{1}\right)$, beban kerja $\left(\mathrm{x}_{2}\right)$, motivasi kerja $\left(\mathrm{x}_{3}\right)$ maka kepuasan kerja pegawai di Sub Bagian Kepegawaian dan Keuangan Dinas Pertanian Provinsi Daerah Istimewa Yogyakarta adalah sebesar 1,284.

2) Koefisien regresi kompensasi $\left(\mathrm{x}_{1}\right)$ sebesar 0,714 menyatakan bahwa setiap penambahan 1 poin kompensasi $\left(\mathrm{x}_{1}\right)$ akan meningkatkan kepuasan kerja pegawai (y) di Sub Bagian Kepegawaian dan Keuangan Dinas Pertanian Provinsi Daerah Istimewa Yogyakarta adalah sebesar 0,714.

3) Koefisien regresi beban kerja $\left(\mathrm{x}_{2}\right)$ sebesar 0,241 menyatakan bahwa setiap penambahan 1 poin kompensasi $\left(\mathrm{x}_{2}\right)$ akan meningkatkan kepuasan kerja pegawai (y) di Sub Bagian Kepegawaian dan Keuangan Dinas Pertanian Provinsi Daerah Istimewa Yogyakarta adalah sebesar 0,241.

4) Koefisien regresi kompensasi $\left(\mathrm{x}_{3}\right)$ sebesar 0,269 menyatakan bahwa setiap penambahan 1 poin motivasi kerja $\left(\mathrm{x}_{3}\right)$ akan meningkatkan kepuasan kerja pegawai (y) di Sub Bagian Kepegawaian dan Keuangan Dinas Pertanian Provinsi Daerah Istimewa Yogyakarta adalah sebesar 0,269.

5) Kompensasi memiliki pengaruh yang lebih besar daripada beban kerja dan motivasi kerja. Hal ini dapat dibuktikan dari koefisien regresi nilai kompensasi sebesar 0,714, sedangkan hasil koefisien regresi beban kerja dan motivasi kerja masing-masing sebesar 0,293 dan 0,057.

Uji Hipotesis

\section{Uji Signifikansi Parsial (Uji T)}

Tabel.7 Hasil Uji Parsial dengan T-Test

\begin{tabular}{ccccc}
\hline Variabel Bebas & T-hitung & T-tabel & Probabilits & Keterangan \\
\hline Kompensasi & 2,194 & 2,056 & 0,037 & Berpengaruh \\
Beban Kerja & 0,870 & 2,056 & 0,392 & Tidak Berpengaruh \\
Motivasi Kerja & 2,149 & 2,056 & 0,41 & Berpengaruh \\
\hline
\end{tabular}

Sumber: Hasil olah data primer 2021

Berdasarkan ringkasan hasil uji hipotesis tabel 7, hasil pengolahan data variabel kompensasi menunjukkan angka $t_{\text {hitung }}$ sebesar 2,194 sedangkan nilai $t_{\text {tabel }}$ sebesar 2,056. Dari hasil perhitungan diperoleh koefisien regresi kompensasi $\left(\mathrm{x}_{1}\right)$ 0,714 menyatakan bahwa setiap penambahan 1 poin kompensasi akan meningkatkan kepuasan kerja pegawai (y) sebesar 0,714, sehingga dapat disimpulkan berpengaruh. Dengan demikian diperoleh nilai $t_{\text {hitung }}>t_{\text {tabel }}=2,194>2,056$ dan nilai signifikansi sebesar 0,037 ( $\mathrm{sig}<$ $0,05)$. Berdasarkan hasil analisis tersebut dapat disimpulkan bahwa variabel kompensasi $\left(\mathrm{x}_{1}\right)$ berpengaruh signifikan terhadap kepuasan kerja $(\mathrm{y})$, sehingga hipotesis 1 dapat 
diterima.

Secara teoritis hasil ini didukung oleh penelitian sebelumnya yang dilakukan oleh Zaki dan Marzolina (2018), hasil penelitian tersebut menyatakan bahwa kompensasi berpengaruh positif dan signifikan terhadap kepuasan kerja pegawai yang bersangkutan. Hal ini berarti kompensasi merupakan suatu yang penting bagi pegawai sebagai makhluk individu, dengan pemberian kompensasi yang layak dan sesuai dengan standar maka pegawai akan merasa puas. Pendapat tersebut sejalan dengan asas-asas kompensasi yang dikemukakan oleh Hasibuan (2014:122) kompensasi harus ditetapkan atas asas adil dan layak serta dengan memerhatikan undang-undang perburuhan yang berlaku. Prinsip adil dan layak harus mendapat perhatian dengan sebaik-baiknya agar balas jasa yang akan diberikan memeberikan kepuasan kerja bagi pegawai.

Hasil penelitian pengujian pada hipotesis 2, pada variabel beban kerja menunjukkan angka $t_{\text {hitung }}$ sebesar 0,870 sedangkan nilai $t_{\text {tabel }}$ sebesar 2,056. Dari hasil perhitungan yang diperoleh koefisien regresi beban kerja $\left(\mathrm{x}_{2}\right)$ sebesar 0,241 menyatakan bahwa setiap penambahan 1 poin beban kerja akan meningkatkan kepuasan kerja pegawai (y) sebesar 0,241 poin. Peningkatan ini berpengaruh sangat kecil, sehingga dapat disimpulkan tidak berpengaruh. Dengan demikian diperoleh nilai $t$ hitung $<\mathrm{t}$ tabel $=0,870<2,056$ dan nilai signifikansi sebesar 0,392 (sig $>0,05)$. Berdasarkan hasil analisis tersebut dapat disimpulkan bahwa variabel beban kerja $\left(\mathrm{x}_{2}\right)$ tidak berpengaruh terhadap kepuasan pegawai (y), sehingga hipotesis 2 ditolak.

Berdasarkan hasil tersebut masih ada pengaruh beban kerja terhadap kepuasan kerja pegawai meskipun kecil, sehingga dapat disimpulkan bahwa beban kerja tidak memengaruhi kepuasan kerja pegawai. Beban kerja tidak secara otomatis memengaruhi kepuasan kerja pegawai. Artinya beban kerja bukan sebagai prediktor variabel kepuasan kerja. Dari jawaban pernyataan kuesioner dan pengamatan yang dilakukan oleh peneliti, beban kerja tetap dirasakan oleh pegawai namun para pegawai mengerjakan pekerjaan dengan senang hati dan sesuai dengan keahlian masing-masing.

Hasil penelitian pengujian hipotesis 3 , pada variabel motivasi kerja menunjukkan angka $\mathrm{t}_{\text {hitung }}$ sebesar 2,149 sedangkan nilai $\mathrm{t}_{\text {tabel }}$ sebesar 2,056. Dari hasil perhitungan yang diperoleh koefisien regresi motivasi kerja $\left(\mathrm{X}_{3}\right)$ sebesar 0,269 menyatakan bahwa setiap penambahan 1 poin motivasi kerja akan meningkatkan kepuasan pegawai (Y) sebesar 0,269 poin, sehingga dapat disimpulkan berpengaruh. Dengan demikian diperoleh nilai thitung $<\mathrm{t}$ tabel $=2,149>2,057$ dan nilai signifikansi sebesar $0,041(\mathrm{sig}>0,05)$. Berdasarkan hasil analisis tersebut dapat disimpulkan bahwa variabel motivasi kerja $\left(\mathrm{x}_{3}\right)$ berpengaruh terhadap kepuasan kerja pegawai $(\mathrm{y})$, sehingga hipotesis 3 diterima.

Motivasi kerja yang tinggi memengaruhi kepuasan kerja pada pegawai. Adanya kepuasan terhadap pekerjaan yang diekspresikan pada rasa senang terhadap pekerjaannya. Apabila pekerjaan dapat dilaksanakan dengan baik, dan kebutuhan pegawai terpenuhi maka akan menumbuhkan kepuasan kerja. Hubungan baik sesama pegawai di Sub Bagian Kepegawaian dan Keuangan Dinas Pertanian Provinsi Daerah Istimewa akan menciptakan suasana nyaman, akrab dan saling mendukung, sehingga 
pegawai akan merasa senang dalam melaksanakan pekerjaannya. Pegawai akan merasa bahwa perusahaan memberi kesempatan untuk maju akan merasa puas pada saat target pekerjaan terpenyusruhi. Seperti penelitian sebelumnya yang telah dilakukan oleh Parimita dkk (2018) bahwa motivasi kerja memiliki pengaruh positif dan signifikan terhadap kepuasan kerja pada karayawan PT Tridaya Eramina Bahari. Jika motivasi kerja meningkat, maka kepuasan kerja juga akan meningkat. Pendapat tersebut didukung oleh tujuan motivasi yang dikemukakan oleh Hasibuan (2014:146) bahwa tujuan motivasi salah satunya adalah meningkatkan moral dan kepuasan kerja pegawai.

\section{Uji Signifikansi dengan F-Test}

Uji $\mathrm{F}$ digunakan untuk mengetahui pengaruh signifikan variabel-variabel independen secara bersama-sama. Taraf signifikansi yang digunakan adalah 0,05 . Jika $\mathrm{f}_{\text {hitung }}$ lebih besar dari $\mathrm{f}_{\text {tabel}}$, maka hipotesis alternatif yang menyatakan bahwa semua variabel independen secara bersama-sama berpengaruh signifikan terhadap variabel dependen. Dengan taraf kepercayaan 95\% (taraf signifikansi 5\% atau 0,05 dan derajat bebas $1(\mathrm{df} 1)=\mathrm{k}$ (Jumlah variabel $)-1=4-1=3$ dan derajat bebas $2(\mathrm{df} 2)=\mathrm{n}-\mathrm{k}-1=30$ $3-1=26, n=$ jumlah sampel dan $\mathrm{k}=$ variabel independen (Sugiyono:2009).

Berdasarkan uji F yang telah dilakukan dengan SPSS versi 22 maka diperoleh hasil sebagai berikut:

Tabel 8. Hasil Uji Signifikansi dengan F-Test

\begin{tabular}{lccccc}
\hline \multicolumn{1}{c}{ Model } & Sum of Squares & Df & Mean Square & F & Sig \\
\hline Regression & 184,357 & 3 & 61,452 & 4,545 & 0,011 \\
Residual & 351,510 & 26 & 13,520 & & \\
\hline Total & 535,856 & 29 & & & \\
\hline
\end{tabular}

a. Dependent Variabel: Kepuasan Kerja Pegawai

b. Predictors: (Constant) Motivasi Kerja, Beban Kerja, Kompensasi

Sumber: hasil olah data primer 2021

Berdasakan ringkasan hasil uji signifikansi dengan uji $\mathrm{F}$, diperoleh $\mathrm{f}_{\text {hitung }}>\mathrm{f}_{\text {tabel }}$ $=4,545>2,98$. Dari hasil analisis regresi linier berganda menunjukkan $Y=1,284+$ $0,714 \mathrm{x}_{1}+0,241 \mathrm{x}_{2}+0,269 \mathrm{x}_{3}$. Hasil uji F menunjukkan ${ }_{\text {Fhitung }}$ sebesar 4,545 dan lebih besar dari $\mathrm{f}_{\text {tabel }}$ sebesar 2,98. Hal tersebut menyatakan bahwa terdapat pengaruh positif dan signifikan kompensasi, beban kerja, dan motivasi kerja secara bersama-sama terhadap kepuasan kerja pegawai di Sub Bagian Kepegawaian dan Keuangan Dinas Pertanian Provinsi Daerah Istimewa Yogyakarta, sehingga hipotesis 4 dapat diterima. 


\section{Uji Koefisien Determinasi $\left(\mathbf{R}^{2}\right)$}

Tabel 9. Hasil Uji koefisien determinasi

\begin{tabular}{ccccc}
\hline Model & R & R Square & Adjusted R Square & Std. Error of the Estimate \\
\hline 1 & $0,587^{\mathrm{a}}$ & 0,344 & 0,268 & 3,677 \\
\hline
\end{tabular}

Sumber: hasil olah data primer 2021

Berdasarkan tabel di atas, diketahui bahwa nilai koefisien determinasi (Adjusted $R$ Square) sebsesar 0,268. Artinya variabel bebas yaitu kompensasi $\left(\mathrm{x}_{1}\right)$, beban kerja $\left(\mathrm{x}_{2}\right)$, motivasi kerja $\left(\mathrm{X}_{3}\right)$ mampu menjelaskan variabel terikat yaitu variabel kepuasan kerja (y) sebesar 26,8\%, dan sisanya dipengaruhi oleh variabel lain di luar penelitian ini.

\section{PEMBAHASAN}

Penelitian ini bertujuan untuk mengetahui pengaruh kompensasi, beban kerja dan motivasi kerja terhadap kepuasan kerja pegawai di Sub Bagian Kepegawaian dan Keuangan Dinas Pertanian Provinsi Daerah Istimewa Yogyakarta. Berdasarkan data yang telah dianalisis, maka dapat diuraikan dengan melakukan pembahasan sebagai berikut:

1) Pengaruh Kompensasi terhadap Kepuasan Kerja Pegawai

Pada penelitian ini kompensasi berpengaruh secara signifikan terhadap kepuasan kerja pegawai di Sub Bagian Kepegawaian dan Keuangan Dinas Pertanian Provinsi Daerah Istimewa Yogyakarta. Hal tersebut dilihat dari nilai t hitung dari uji signifikan dengan dengan T-Test yang diperoleh sebesar 2,194, sedangkan $\mathrm{t}$ tabel pada signifikansi 5\% dan derajat bebas (df) 26 adalah sebesar 2,056 (t hitung $>\mathrm{t}$ tabel).

Berdasarkan hasil tersebut naiknya kepuasan kerja pegawai disebabkan antara lain pegawai selalu menerima gaji tepat waktu dan sesuai dengan pekerjaan yang dikerjakan, serta pihak dinas memerhatikan kebutuhan dan fasilitas pegawai termasuk tunjangan. Hasil penelitian ini sesuai dengan hasil penelitian dari Wahyuni dan Irfani yang berjudul Pengaruh kompensasi dan beban kerja terhadap kepuasan kerja dalam meningkatkan kinerja karyawan PT. Kepsindo Indra Utama Padang, yang memiliki hasil kompensasi berpengaruh positif terhadap kepuasan kerja karyawan.

2) Pengaruh Beban Kerja terhadap Kepuasan Kerja Pegawai

Pada penelitian ini beban kerja tidak berpengaruh secara signifikan terhadap kepuasan kerja pegawai di Sub Bagian Kepegawaian dan Keuangan Dinas Pertanian Provinsi Daerah Istimewa Yogyakarta. Hal tersebut dilihat dari nilai t hitung dari uji signifikan dengan dengan T-Test yang diperoleh sebesar 0,870 , sedangkan $t$ tabel pada signifikansi 5\% dan derajat bebas (df) 26 adalah sebesar 2,056 (t hitung $<\mathrm{t}$ tabel). 
Berdasarkan hasil tersebut masih ada pengaruh beban kerja terhadap kepuasan kerja pegawai meskipun sangat kecil, sehingga dapat disimpulkan bahwa beban kerja tidak memengaruhi kepuasan kerja pegawai. Beban kerja tidak secara otomatis memengaruhi kepuasan kerja pegawai. Artinya beban kerja bukan sebagai prediktor variabel kepuasan kerja. Dari jawaban pernyataan kuesioner dan pengamatan yang dilakukan oleh peneliti, beban kerja tetap dirasakan oleh pegawai namun para pegawai mengerjakan pekerjaan dengan senang hati dan sesuai dengan keahlian masing-masing.

3) Pengaruh Motivasi Kerja terhadap Kepuasan Kerja Pegawai

Pada penelitian ini motivasi kerja berpengaruh secara signifikan terhadap kepuasan kerja pegawai di Sub Bagian Kepegawaian dan Keuangan Dinas Pertanian Provinsi Daerah Istimewa Yogyakarta. Hal tersebut dilihat dari nilai t hitung dari uji signifikan dengan dengan T-Test yang diperoleh sebesar 2,149, sedangkan $t$ tabel pada signifikansi 5\% dan derajat bebas (df) 26 adalah sebesar 2,056 ( $\mathrm{t}$ hitung $>\mathrm{t}$ tabel).

Motivasi kerja yang tinggi memengaruhi kepuasan kerja pada pegawai. Adanya kepuasan terhadap pekerjaan yang diekspresikan pada rasa senang terhadap pekerjaannya. Apabila pekerjaan dapat dilaksanakan dengan baik, dan kebutuhan pegawai terpenuhi maka akan menumbuhkan kepuasan kerja. Hubungan baik sesama pegawai di Sub Bagian Kepegawaian dan Keuangan Dinas Pertanian Provinsi Daerah Istimewa akan menciptakan suasana nyaman, akrab dan saling mendukung, sehingga pegawai akan merasa senang dalam melaksanakan pekerjaannya. Pegawai akan merasa bahwa perusahaan memberi kesempatan untuk maju akan merasa puas pada saat target pekerjaan terpenuhi.

Dengan ini dapat disimpulkan bahwa peranan motivasi kerja berpengaruh terhadap kepuasan kerja pegawai di Sub Bagian Kepegawaian dan Keuangan Dinas Pertanian Provinsi Daerah Istimewa. Hasil penelitian ini juga sesuai dengan penelitian Rozzald, Herlambang dan Devi (2015) dengan judul Pengaruh kompensasi dan motivasi terhadap kepuasan kerja karyawan pada PT. Nusapro Telemedia Persada Cabang Banyuwangi, yang menyatakan bahwa motivasi berpengaruh positif terhadap kepuasan kerja karyawan. Karyawan yang memiliki motivasi kerja yang tinggi maka kepuasan kerjanya juga akan meningkat.

4) Pengaruh Kompensasi, Beban Kerja dan Motivasi Kerja terhadap Kepuasan Kerja Pegawai

Dari hasil analisis regresi linier berganda menunjukkan $\mathrm{Y}=1,284+0,714 \mathrm{x}_{1}+$ $0,241 \mathrm{x}_{2}+0,269 \mathrm{x}_{3}$. Hasil uji $\mathrm{F}$ menunjukkan $\mathrm{F}$ hitung sebesar 4,545 dan lebih besar dari $\mathrm{F}$ tabel sebesar 2,98. Hal tersebut terdapat pengaruh positif dan signifikan kompensasi, beban kerja, dan motivasi kerja secara bersama-sama terhadap kepuasan kerja pegawai di Sub Bagian Kepegawaian dan Keuangan Dinas Pertanian Provinsi Daerah Istimewa Yogyakarta. Besarnya pengaruh kompensasi, beban kerja dan motivasi kerja terhadap kepuasan kerja pegawai 
di Sub Kepegawaian dan Keuangan Dinas Pertanian Provinsi Daerah Istimewa Yogyakarta sebesar 26,8\%. Hal ini berarti pengaruh sebesar 26,8\% memberikan informasi bahwa kompensasi, beban kerja dan motivasi kerja berpengaruh terhadap kepuasan kerja pegawai di Sub Bagian Kepegawaian dan Keuangan Dinas Pertanian Provinsi Daerah Istimewa Yogyakarta.

Berdasarkan analisis tersebut dapat disimpulkan bahwa kompensasi, beban kerja dan motivasi kerja secara bersama-sama berpengaruh terhadap kepuasan kerja pegawai di Sub Bagian Kepegawaian dan Keuangan Dinas Pertanian Provinsi Daerah Istimewa Yogyakarta.

\section{E. SIMPULAN}

Berdasarkan hasil analisis data yang telah diuraikan, maka dapat disimpulkan sebagai berikut:

1) Berdasarkan hasil analisis regresi linier berganda diperoleh koefisien regresi variabel kompensasi (X1), beban kerja (X2), dan motivasi kerja (X3) bertanda positif $(+)$ yang menandakan hubungan searah. Hal ini berarti kompensasi, beban kerja dan motivasi kerja meningkatkan kepuasan kerja pegawai di Sub Bagian Kepegawaian dan Keuangan Dinas Pertanian Provinsi Daerah Istimewa Yogyakarta.

2) Berdasarkan hasil pengujian signifikansi secara parsial dengan T-Test menunjukkan bahwa kompensasi berpengaruh secara signifikan positif terhadap kepuasan kerja pegawai.

3) Berdasarkan hasil pengujian signifikansi secara parsial dengan T-Test menunjukkan bahwa beban kerja tidak berpengaruh terhadap kepuasan kerja pegawai.

4) Berdasarkan hasil pengujian signifikansi secara parsial dengan T-Test menunjukkan bahwa motivasi kerja berpengaruh terhadap kepuasan kerja pegawai.

5) Berdasarkan hasil pengujian signifikansi dengan F-test, menunjukkan bahwa variabel kompensasi, beban kerja dan motivasi kerja secara bersama-sama (simultan) berpengaruh terhadap kepuasan kerja pegawai di Sub Bagian Kepegawaian dan Keuangan Dinas Pertanian Provinsi Daerah Istimewa Yogyakarta.

6) Berdasarkan nilai koefisien determinasi (Adjusted $R$ Square) sebesar 0,268, maka hal ini menunjukkan bahwa 26,8\% kepuasan kerja pegawai dipengaruhi kompensasi, beban kerja dan motivasi kerja. Sisanya 73,2\% dipengaruhi oleh variabel lain yang tidak digunakan dalam penelitian ini.

\section{DAFTAR PUSTAKA}

Damayanti, Riski, Agustina Hanafi dan Afriadi Cahyadi. (2018) "Pengaruh Kepuasan Kerja Karyawan Non Medis di RS Islam Siti Khadijah Palembang”. Jurnal Ilmiah Manajemen Bisnis dan Terapan Tahun XV, Vol 15, No 2 (Oktober): 75-86. 
Handoko,T. Hani. (2012) Manajemen Personalia dan Sumber Daya Manusia. Yogyakarta: BPFE.

Hasibuan, Malayu.(2014) Manajemen Sumber Daya Manusia. Jakarta: Bumi Aksara. Koesomowidjojo, Mar' ih R. Suci. (2017) PANDUAN PRAKTIS MENYUSUN Analisis Beban Kerja. Jakarta: Raih Asa Sukses.

Paramitadewi, Ferrania K. (2017) "Pengaruh Beban Kerja Dan Kompensasi Terhadap Kinerja Pegawai Sekretaruat Pemerintah Daerah Kabupaten Tabanan. E-Jurnal Manajemen Unud", Volume 6 No.6, 2017 hlm 3370-3397. ISSN : 2302-8912

Paramita, Widya, Siti Khoiriyah dan Agung Wahyu Handaru.(2018) "Pengaruh Motivasi Kerja dan Kompensasi Terhadap Kepuasan Kerja Pada Karyawan PT Tridaya Eramina Bahari”. Jurnal Riset Manajemen Sains Indonesia (JRMSI), Vol 9, No.1: 125-144.

Peraturan Menteri Dalam Negeri Nomor 12 Tahun 2008 tentang Pedoman Analisis Beban Kerja Di Lingkungan Departemen Dalam Negeri Dan Pemerintah Daerah.

Pontoh, Farham M.(2014) “Pengaruh Kompensasi Dan Beban Kerja Terhadap Kepuasan Kerja Dan Dampaknya Pada Kinerja Pegawai Pada Badan Perencanaan Pembangunan Daerah Propinsi Sulawesi Tengah". e-Jurnal Katalogis, Volume 2 Nomor 1, Januari 2014 hlm 101-113. ISSN: 2302-2019.

Sedarmayanti. (2017) Perancangan dan Pengembangan Sumber Daya Manausia Untuk Meningkatkan Kompetensi, Kinerja, dan Produktivitas Kerja. Bandung: Refika Aditama.

Sekaran, Uma and Bougie Roger. (2010) Research Methode for Business: A Skill Building Approach. United Kingdom: John Wiley \& Sohs Ltd.

Sugiyono. (2018) Metode Penelitian Kuantitatif, Kualitatif dan R\&D. Bandung: Alfabeta.

Sulistiyani, Ambar Teguh dan Rosidah. (2018) MANAJEMEN SUMBER DAYA MANUSIA Pendekatan Teoritik dan Praktik Untuk Organisasi Publik. Yogyakarta: Gava Media.

Supriyanto, Achmad Sani dan Vivin Maharani. (2013) Metodologi Penelitian Sumber Daya Manusia: Teori, Kuesioner, dan Analisis Data. Malang: UIN-MALIKI PRESS.

Zaki, Hammam dan Marzolina. (2018) "Pengaruh Beban Kerja dan Kompensasi Terhadap Kepuasan Kerja dan Turnover Intention Karyawan PT Quantum Multi Finance Cabang Pekanbaru". Jurnal Akuntansi dan Ekonomika, Vol.8, No.1(Juni): 108-117 
